\title{
Distribution of Free and Bound Phenolic Compounds in Buckwheat Milling Fractions
}

\author{
Beatriz Martín-García ${ }^{1}$, Federica Pasini ${ }^{2}$, Vito Verardo ${ }^{3,4, *} \mathbb{1}$, Ana María Gómez-Caravaca ${ }^{1}$, \\ Emanuele Marconi ${ }^{5}$ and Maria Fiorenza Caboni ${ }^{2,6}$ \\ 1 Department of Analytical Chemistry, Faculty of Sciences, University of Granada, Avd. Fuentenueva s/n, \\ 18071 Granada, Spain; bearu15@correo.ugr.es (B.M.-G.); anagomez@ugr.es (A.M.G.-C.) \\ 2 Department of Agricultural and Food Sciences, University of Bologna, Piazza Goidanich 60, \\ (FC) 47521 Cesena, Italy; federica.pasini5@unibo.it (F.P.); maria.caboni@unibo.it (M.F.C.) \\ 3 Department of Nutrition and Food Science, University of Granada, Campus of Cartuja, 18071 Granada, Spain \\ 4 Institute of Nutrition and Food Technology 'José Mataix', Biomedical Research Center, University of \\ Granada, Avda del Conocimiento sn., 18100 Armilla, Granada, Spain \\ 5 Dipartimento Agricoltura, Ambiente e Alimenti, Università del Molise, via De Sanctis s/n, \\ I-86100 Campobasso, Italy; marconi@unimol.it \\ 6 Interdepartmental Centre for Agri-Food Industrial Research, Alma Mater Studiorum, Università di Bologna, \\ via Quinto Bucci 336, 47521 Cesena (FC), Italy \\ * Correspondence: vitoverardo@ugr.es; Tel.: +34-958243863
}

Received: 16 October 2019; Accepted: 9 December 2019; Published: 12 December 2019

check for updates

\begin{abstract}
Buckwheat is a rich source of phenolic compounds that have shown to possess beneficial effect to reduce some diseases due to their antioxidant power. Phenolic compounds are present in the free and in the bound form to the cell wall that are concentrated mainly in the outer layer (hull and bran). Hull is removed before the milling of buckwheat to obtain flours. In order to evaluate the phenolic composition in dehulled buckwheat milling fractions, it was carried out a determination of free and bound phenolic compounds in dehulled whole buckwheat flour, light flour, bran flour, and middling flour by high-performance liquid chromatography-mass spectrometry (HPLC-MS). The most abundant free phenolic compounds were rutin and epiafzelchin-epicatechin-O-dimethylgallate, whereas the most abundant bound phenolic compounds were catechin and epicatechin in all buckwheat flours. Besides, the highest content of free phenolic compounds was obtained in bran flour (1249.49 mg/kg d.w.), whereas the greatest bound phenolic content was in middling (704.47 mg/kg d.w.) and bran flours (689.81 $\mathrm{mg} / \mathrm{kg} \mathrm{d.w.).} \mathrm{Thus,} \mathrm{middling} \mathrm{and} \mathrm{bran} \mathrm{flours} \mathrm{are} \mathrm{naturally} \mathrm{enriched}$ flours in phenolic compounds that could be used to develop functional foods.
\end{abstract}

Keywords: free and bound phenolic compounds; buckwheat flours; HPLC-MS; milling fractions

\section{Introduction}

Buckwheat (Fagopyrum esculentum Moench) as a traditional pseudocereal crop which belongs to the Polygonaceae is extensively utilized as food and as a medicinal plant [1]. Buckwheat is a rich source of starch, protein, and vitamins [2]. In addition, buckwheat is well known for containing phenolic compounds, including phenolic acids such as protocatechuic, syringic acid, and caffeic acid and flavonoids such as rutin (quercetin 3-rutinoside), quercetin, hyperoside (quercetin 3-O-b-D-galactoside), quercitrin (quercetin 3-O-a-L-rhamnoside), epicatechin, orientin, vitexin, isovitexin, and isoorientin [3-5]. Rutin is the most concentrated phenolic compound in Tartary and some common buckwheats, which have a content higher than most other plants [2]. Phenolic compounds in buckwheat have shown to possess antioxidant activity which has been associated with a lower incidence of cardiovascular disease, cancers, and age-related degenerative process [6-10]. 
Phenolic compounds in buckwheat are present in the free and in the bound form to cell wall [11], however, the majority of phenolic compounds are present in the free form, which has a distribution and concentration that is different in each part of the grain: pericarp (hull, husk), coat, endosperm, embryo with axis, and two cotyledons [12]; phenolic compounds are concentrated in the outer layers (hull and bran) of buckwheat grain [2]. Nevertheless, during buckwheat seeds processing into flour, the hull (17-20\% of buckwheat grain) is removed by stone dehuller. The resulting product, called groat (intact achene), is milled into bran flour (10-24\%), which is a by-product that it is not commonly used in foods, and light flour (55-70\%), which consists principally of endosperm and is used in human nutrition [13]. In addition, middling is a by-product from buckwheat milling that is not a flour that comprises different fractions and it includes $12 \%$ of the original grain, consisting of fractions of endosperm, bran, and germ [14]. Milling techniques used in the food industry employ mechanical force to break the grains into smaller fragments or fine particles. [15]. Previous studies reported the use of roller milling process in dehulled whole buckwheat to obtain a flour and the separation of this flour into various fractions from outer to inner parts $[2,16]$. These studies have shown that outer layers are richer in protein, lipid, dietary fiber, and ash content than the inner layers. Also, the antioxidant capacity in flour fractions in the outer layers is higher than that in the inner layers by the increase of phenolic compounds from bran $[2,16]$. In addition, it has reported that milling fractions that contain outer layers possess a higher concentration of phenolic compounds than whole grain and groat flour fractions [6]. Therefore, the aim of this work was the determination of free and bound phenolic content in different buckwheat meals/flours: whole grain flour, light flour, bran meals, and middling flour in order to evaluate the phenolic concentration in each buckwheat meal fraction. These analyses will furnish new information about the total content of phenolic compounds in each fraction, taking into account the free or extractable fraction and bound or nonextractable phenolic fraction (NEPP). For that purpose, phenolic compounds were extracted and then were analyzed by high-performance liquid chromatography-mass spectrometry (HPLC-MS).

\section{Materials and Methods}

\subsection{Sample}

Buckwheat meals/flours were obtained from whole buckwheat grain (cv. Darja) harvested in Matrice (Italy) $\left(41^{\circ} 37^{\prime} 00^{\prime \prime} \mathrm{N} 14^{\circ} 43^{\prime} 00^{\prime \prime} \mathrm{E}\right)$, situated in a hilly location at $750 \mathrm{~m}$ above sea level. The field presented high tenacity of the soil due to the presence of clay. Harvesting took place on September 2018. The grain was dehulled by stone dehuller (GRANO 200 SCHNITZER Stein-Getreidemuhle, Offenburg, Germany), and the groat (dehulled grain) was roller-milled by using an experimental mill (Labormill 4RB Bona, Monza, Italy). This mill is able to produce three milling fractions with different particle sizes that constituted the basis for differentiation between bran meal, middling flour, and light flour (Figure 1). In the bran meal, the majority of particles were $>505 \mu \mathrm{m}$, while in middling flour, between $219-363 \mu \mathrm{m}$, and in light flour, $<183 \mu \mathrm{m}$. Granulometry analysis was performed using an automatic sieve (Buhler ML1-300, Uzwil, Switzerland). 


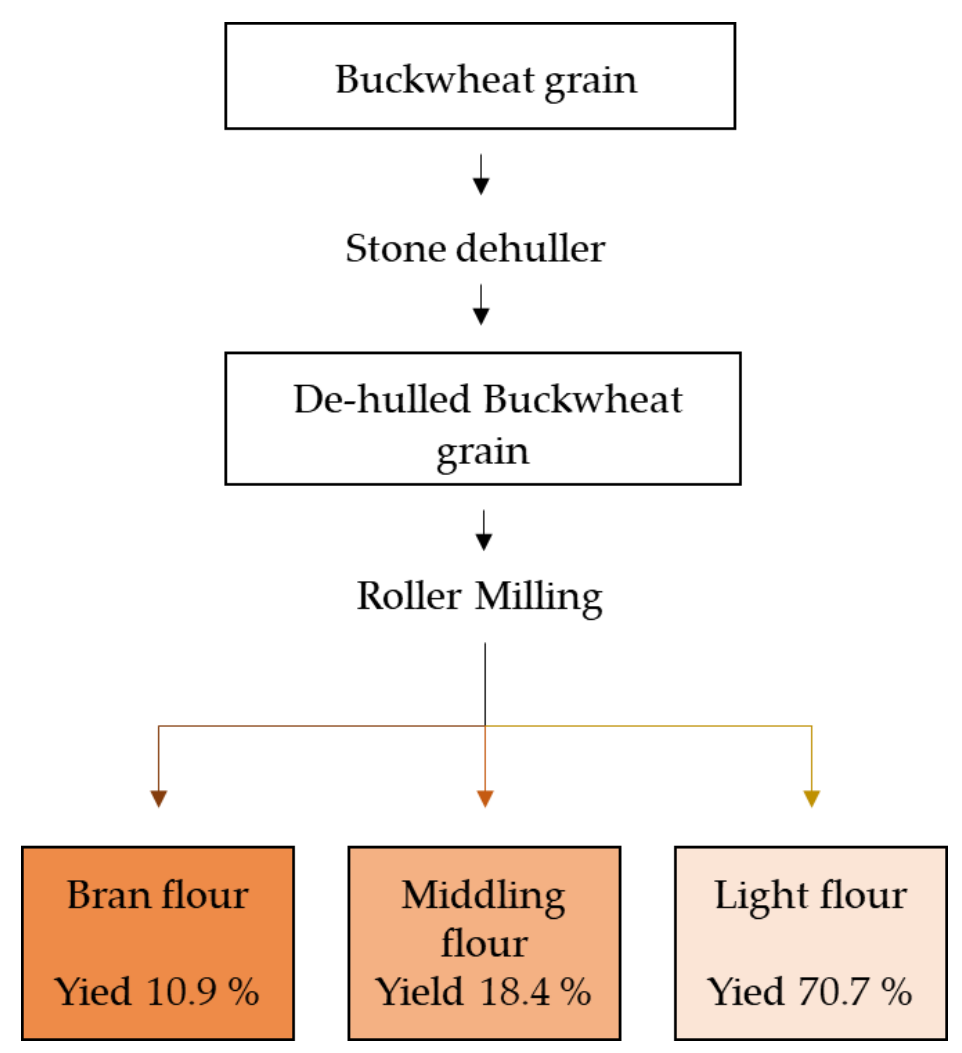

Figure 1. Flowchart of the milling process used for the production of buckwheat flours.

\subsection{Reagents and Chemicals}

HPLC-grade acetonitrile, water, methanol, acetone, acetic acid, ethanol, hexane, ethyl acetate, diethyl ether, and hydrochloric acid were purchased from Merck KGaA (Darmstadt, Germany). Hydroxide sodium was from Fluka (Buchs, Switzerland). Ferulic acid, catechin, quercetin, and rutin (Sigma-Aldrich (St. Louis, MO, USA)) were used for the calibration curves.

\subsection{Extraction Method}

Extraction of free phenolic compounds from buckwheat flour fractions has been carried out according with the method established by Hung \& Morita (2008) [2] with certain modifications. One gram of buckwheat flour was extracted thrice in an ultrasonic bath with a solution of ethanol/water $(4: 1 \mathrm{v} / \mathrm{v})$. The supernatants were collected, centrifugated at $2500 \mathrm{rpm}$ for 10 minutes, evaporated, and reconstituted with $1 \mathrm{~mL}$ of methanol/water $(1: 1 \mathrm{v} / \mathrm{v})$. The extracts were stored at $-18{ }^{\circ} \mathrm{C}$ until use.

Extraction of bound phenolic compounds was carried out according to the method established by Verardo et al. (2011) [5]: residues of free phenolic extraction were digested with $25 \mathrm{~mL}$ of $1 \mathrm{M} \mathrm{NaOH}$ at room temperature for $18 \mathrm{~h}$ by shaking under nitrogen gas. The mixture was acidified ( $\mathrm{pH} 2.2-2.5)$ with hydrochloric acid in a cooling ice bath and extracted with $250 \mathrm{~mL}$ of hexane to remove the lipids. The aqueous solution was extracted five times with $50 \mathrm{~mL}$ of $1: 1$ diethyl ether/ethyl acetate $(v / v)$. The organic fractions were collected and evaporated at $40{ }^{\circ} \mathrm{C}$ in a rotary evaporator. The dry extract was reconstituted in $1 \mathrm{~mL}$ of methanol/water $(1: 1 \mathrm{v} / \mathrm{v})$ and stored at $-18^{\circ} \mathrm{C}$ until use.

\subsection{Determination of Free and Bound Phenolic Compounds by HPLC-MS}

A liquid chromatography apparatus HP 1100 Series (Agilent Technologies, Palo Alto, CA, USA) equipped with a degasser, a binary pump delivery system, and an automatic liquid sampler and coupled to a single quadrupole mass spectrometer detector was used. Separation of free and bound phenolic compounds from buckwheat flour fractions was carried out using a C-18 column (Poroshell 
120, SB-C18, $3.0 \times 100 \mathrm{~mm}, 2.7 \mu \mathrm{m}$ from Agilent Technologies, Palo Alto, CA, USA). The gradient elution was the same as that previously established by Gómez-Caravaca et al. [17] using as a mobile phase A acidified water (1\% acetic acid) and as mobile phase B acetonitrile. MS analysis was carried out using an electrospray ionization (ESI) interface in negative ionization mode at the following conditions: drying gas flow $\left(\mathrm{N}_{2}\right), 9.0 \mathrm{~L} / \mathrm{min}$; nebulizer pressure, 50 psi; gas drying temperature, $350{ }^{\circ} \mathrm{C}$; capillary voltage, $4000 \mathrm{~V}$. The fragmentor and $\mathrm{m} / \mathrm{z}$ range used for HPLC-ESI/MS analyses were $80 \mathrm{~V}$ and m/z 50-1000, respectively. Data were processed by the software MassHunter Workstation Qualitative Analysis Version B.07.00 (Agilent Technologies, Santa Clara, CA, USA).

\subsection{Statistical Analysis}

The results of quantification reported in this work are the averages of three repetitions $(n=3)$. Tukey's honest significant difference multiple comparison (one-way ANOVA) at the $p<0.05$ level was evaluated by using the Statistica 7.0 software (StatSoft, Tulsa, OK, USA)

\section{Results and Discussion}

\subsection{Analytical Parameters of the Method}

An analytical validation of the method was performed considering linearity and sensitivity. In order to quantify phenolic compounds in buckwheat fractions, five calibrations curves were elaborated with the standards ferulic acid, catechin, quercetin, gallic acid, and rutin. Table 1 includes the analytical parameters of the standards used, containing calibration ranges, calibration curves, determination coefficients, limit of detection (LOD), and limit of quantification (LOQ).

Table 1. Analytical parameters of the method proposed.

\begin{tabular}{cccccc}
\hline Standards & $\begin{array}{c}\text { Calibration } \\
\text { Ranges (mg/L) }\end{array}$ & Calibration Curves (mg/g) & $\boldsymbol{r}^{\mathbf{2}}$ & LOD (mg/L) & LOQ (mg/L) \\
\hline Ferulic acid & LOQ-100 & $y=119572 x+16157$ & 0.9995 & 0.0136 & 0.0452 \\
Catechin & LOQ-100 & $y=170925 x+8609.5$ & 0.9994 & 0.0095 & 0.0316 \\
Quercetin & LOQ-100 & $y=402162 x+44862$ & 0.9996 & 0.0040 & 0.0134 \\
Gallic acid & LOQ-100 & $y=123892 x-4971.6$ & 0.9984 & 0.0131 & 0.0437 \\
Rutin & LOQ-100 & $y=199694 x-2067.2$ & 0.9999 & 0.0081 & 0.0271 \\
\hline
\end{tabular}

LOD: Limit of detection, LOQ: Limit of quantification.

Calibration curves were carried out by using the peak areas analyte standard against the concentration of the analyte for the analysis by HPLC. The external calibration of the standards was elaborated at different concentration levels from LOQ to $100 \mathrm{mg} \mathrm{L}^{-1}$. All calibration curves revealed good linearity among different concentrations, and the determination coefficients were higher than 0.9994 in all cases. The method used for analysis showed LOD within the range $0.0040-0.0136 \mathrm{mg} \mathrm{L}^{-1}$, the LOQ were within $0.0134-0.0452 \mathrm{mg} \mathrm{L}^{-1}$.

\subsection{Identification of Phenolic Compounds from Buckwheat Extracts by HPLC-MS}

Free and bound phenolic compounds in buckwheat flour fractions extracts were analyzed by HPLC with MS detection, and the identification of these compounds was carried out by comparison of molecular weight in bibliography and when available, by co-elution with commercial standards.

A total of 25 free phenolic compounds were identified in buckwheat flours, among them five were phenolic acids and 20 were flavonoids, and they were previously identified in other works $[4,18]$ (Table 2). 
Table 2. Identification table of free phenolic compounds in buckwheat flours.

\begin{tabular}{|c|c|c|c|c|c|}
\hline Peak & $\begin{array}{l}\text { Retention } \\
\text { Time }\end{array}$ & {$[\mathrm{M}-\mathrm{H}]$} & $\begin{array}{l}\text { Molecular } \\
\text { Formula }\end{array}$ & Compound & $\begin{array}{l}\text { In Source } \\
\text { Fragments }\end{array}$ \\
\hline 1 & 2.1 & 315 & $\mathrm{C}_{13} \mathrm{H}_{15} \mathrm{O}_{9}$ & 2-hydroxy-3- $O$ - $\beta$-D-glucopyranosylbenzoic acid & 153 \\
\hline 2 & 2.6 & 315 & $\mathrm{C}_{13} \mathrm{H}_{15} \mathrm{O}_{9}$ & Protocatechuic-4-O-glucoside acid & 153 \\
\hline 3 & 3.3 & 451 & $\mathrm{C}_{21} \mathrm{H}_{23} \mathrm{O}_{11}$ & Catechin-glucoside & 289 \\
\hline 4 & 4.1 & 341 & $\mathrm{C}_{15} \mathrm{H}_{17} \mathrm{O}_{9}$ & Caffeic acid hexose & 179 \\
\hline 5 & 4.2 & 289 & $\mathrm{C}_{15} \mathrm{H}_{13} \mathrm{O}_{6}$ & Catechin & \\
\hline 6 & 4.4 & 487 & $\mathrm{C}_{21} \mathrm{H}_{27} \mathrm{O}_{13}$ & Swertiamacroside & 179 \\
\hline 7 & 5.0 & 179 & $\mathrm{C}_{9} \mathrm{H}_{7} \mathrm{O}_{4}$ & Caffeic acid & \\
\hline 8 & 5.5 & 289 & $\mathrm{C}_{15} \mathrm{H}_{13} \mathrm{O}_{6}$ & Epicatechin & \\
\hline 9 & 6.2 & 561 & $\mathrm{C}_{30} \mathrm{H}_{25} \mathrm{O}_{11}$ & (Epi)afzelchin-(epi) catechin isomer A & $543,289,271,435$ \\
\hline 10 & 6.8 & 447 & $\mathrm{C}_{21} \mathrm{H}_{19} \mathrm{O}_{11}$ & Orientin & \\
\hline 11 & 7.0 & 447 & $\mathrm{C}_{21} \mathrm{H}_{19} \mathrm{O}_{12}$ & Isorientin & \\
\hline 12 & 7.8 & 431 & $\mathrm{C}_{21} \mathrm{H}_{19} \mathrm{O}_{10}$ & Vitexin & \\
\hline 13 & 7.9 & 609 & $\mathrm{C}_{27} \mathrm{H}_{29} \mathrm{O}_{16}$ & Rutin & \\
\hline 14 & 7.9 & 441 & $\mathrm{C}_{22} \mathrm{H}_{17} \mathrm{O}_{10}$ & Epicatechin-gallate & 289 \\
\hline 15 & 8.0 & 833 & $\mathrm{C}_{45} \mathrm{H}_{37} \mathrm{O}_{16}$ & Epiafzelchin-epiafzelchin-epicatechin & \\
\hline 16 & 8.2 & 487 & $\mathrm{C}_{21} \mathrm{H}_{27} \mathrm{O}_{13}$ & Swertiamacroside & \\
\hline 17 & 8.3 & 463 & $\mathrm{C}_{21} \mathrm{H}_{19} \mathrm{O}_{12}$ & Hyperin & \\
\hline 18 & 8.7 & 727 & $\mathrm{C}_{38} \mathrm{H}_{31} \mathrm{O}_{15}$ & Epiafzelchin-epicatechin-O-methylgallate & $455,289,271$ \\
\hline 19 & 9.4 & 455 & $\mathrm{C}_{23} \mathrm{H}_{19} \mathrm{O}_{10}$ & (-)-Epicatechin-3-(3"-O-methyl) gallate & 289 \\
\hline 20 & 9.5 & 561 & $\mathrm{C}_{30} \mathrm{H}_{25} \mathrm{O}_{11}$ & (Epi)afzelchin-(epi)catechin isomer B & $543,425,289,271$ \\
\hline 21 & 9.9 & 757 & $\mathrm{C}_{39} \mathrm{H}_{33} \mathrm{O}_{16}$ & Procyanidin B2-dimethylgallate & \\
\hline 22 & 10.7 & 741 & $\mathrm{C}_{39} \mathrm{H}_{33} \mathrm{O}_{15}$ & Epiafzelchin-epicatechin-O-dimethylgallate & \\
\hline 23 & 11.5 & 469 & $\mathrm{C}_{24} \mathrm{H}_{21} \mathrm{O}_{10}$ & Epicatechin-O-3,4-dimethylgallate & \\
\hline 24 & 12.3 & 463 & $\mathrm{C}_{21} \mathrm{H}_{19} \mathrm{O}_{12}$ & Isoquercitrin & \\
\hline 25 & 12.6 & 301 & $\mathrm{C}_{15} \mathrm{H}_{10} \mathrm{O}_{7}$ & Quercetin & \\
\hline
\end{tabular}

Twenty-four bound phenolic compounds were identified in buckwheat flours: seven were phenolic acid derivatives and 17 were flavonoids, which were identified in previous works (Table 3) $[5,18]$.

Table 3. Identification of bound phenolic compounds in buckwheat flours.

\begin{tabular}{|c|c|c|c|c|}
\hline Peak & Retention Time & {$[\mathrm{M}-\mathrm{H}]$} & Molecular Formula & Compound \\
\hline 1 & 2.1 & 315 & $\mathrm{C}_{13} \mathrm{H}_{15} \mathrm{O}_{9}$ & 2-hydroxy-3-O- $\beta$-D-glucopyranosylbenzoic acid \\
\hline 2 & 2.6 & 315 & $\mathrm{C}_{13} \mathrm{H}_{15} \mathrm{O}_{9}$ & Protocatechuic-4-O-glucoside acid \\
\hline 3 & 3.2 & 341 & $\mathrm{C}_{15} \mathrm{H}_{17} \mathrm{O}_{9}$ & Caffeic acid hexose isomer a \\
\hline 4 & 4.1 & 341 & $\mathrm{C}_{15} \mathrm{H}_{17} \mathrm{O}_{9}$ & Caffeic acid hexose isomer $\mathrm{b}$ \\
\hline 5 & 4.2 & 289 & $\mathrm{C}_{15} \mathrm{H}_{13} \mathrm{O}_{6}$ & Catechin \\
\hline 6 & 4.4 & 487 & $\mathrm{C}_{21} \mathrm{H}_{27} \mathrm{O}_{13}$ & Swertiamacroside isomer a \\
\hline 7 & 5.0 & 179 & $\mathrm{C}_{9} \mathrm{H}_{7} \mathrm{O}_{4}$ & Caffeic acid \\
\hline 8 & 5.5 & 289 & $\mathrm{C}_{15} \mathrm{H}_{13} \mathrm{O}_{6}$ & Epicatechin \\
\hline 9 & 6.3 & 197 & $\mathrm{C}_{9} \mathrm{H}_{9} \mathrm{O}_{5}$ & Syringic acid \\
\hline 10 & 6.8 & 447 & $\mathrm{C}_{21} \mathrm{H}_{19} \mathrm{O}_{11}$ & Orientin \\
\hline 11 & 6.9 & 163 & $\mathrm{C}_{9} \mathrm{H}_{7} \mathrm{O}_{3}$ & $p$-coumaric acid derivative \\
\hline 12 & 7.0 & 575 & $\mathrm{C}_{30} \mathrm{H}_{23} \mathrm{O}_{12}$ & Procyanidin A \\
\hline 13 & 7.5 & 317 & $\mathrm{C}_{15} \mathrm{H}_{9} \mathrm{O}_{8}$ & Myricetin \\
\hline 14 & 7.8 & 431 & $\mathrm{C}_{21} \mathrm{H}_{19} \mathrm{O}_{10}$ & Vitexin \\
\hline 15 & 7.9 & 609 & $\mathrm{C}_{27} \mathrm{H}_{29} \mathrm{O}_{16}$ & Rutin \\
\hline 16 & 7.9 & 441 & $\mathrm{C}_{22} \mathrm{H}_{17} \mathrm{O}_{10}$ & Epicatechin gallate \\
\hline 17 & 8.2 & 451 & $\mathrm{C}_{21} \mathrm{H}_{23} \mathrm{O}_{11}$ & Catechin-glucoside \\
\hline 18 & 8.2 & 487 & $\mathrm{C}_{21} \mathrm{H}_{27} \mathrm{O}_{13}$ & Swertiamacroside isomer $b$ \\
\hline 19 & 8.7 & 727 & $\mathrm{C}_{38} \mathrm{H}_{31} \mathrm{O}_{15}$ & Epiafzelchin-epicatechin-O-methylgallate \\
\hline 20 & 9.3 & 163 & $\mathrm{C}_{9} \mathrm{H}_{7} \mathrm{O}_{3}$ & $p$-coumaric acid \\
\hline 21 & 9.4 & 455 & $\mathrm{C}_{23} \mathrm{H}_{19} \mathrm{O}_{10}$ & (-)-epicatechin-3-(3"-O-methyl) gallate \\
\hline 22 & 11.5 & 469 & $\mathrm{C}_{24} \mathrm{H}_{21} \mathrm{O}_{10}$ & Epicatechin-O-3,4-dimethylgallate \\
\hline 23 & 12.3 & 463 & $\mathrm{C}_{21} \mathrm{H}_{19} \mathrm{O}_{12}$ & Isoquercitrin \\
\hline 24 & 12.6 & 301 & $\mathrm{C}_{15} \mathrm{H}_{10} \mathrm{O}_{7}$ & Quercetin \\
\hline
\end{tabular}

\subsection{Quantification of Free and Bound Phenolic Compounds in Buckwheat Fractions}

Free phenolic compounds were quantified through of calibration curves of standards. A total of 25 free phenolic compounds were quantified in buckwheat meals/flours: de-hulled grain meal, bran meal, middling flour, and light flour (Table 4). 
Table 4. Free phenolic compounds quantified in buckwheat meals/flours (mg/kg d.w.) determined by HPLC-MS.

\begin{tabular}{|c|c|c|c|c|}
\hline Free Phenolic Compounds & Bran Meal & Middling Flour & Light Flour & De-hulled Grain Meal \\
\hline 2-hydroxy-3-O- $\beta$-Dglucopyranosylbenzoic acid & $42.17^{\mathrm{b}}$ & $78.22^{a}$ & $2.67^{\mathrm{d}}$ & $32.71^{\mathrm{c}}$ \\
\hline Protocatechuic-4-O-glucoside acid & $79.69^{b}$ & $120.59^{\text {a }}$ & $2.93^{\mathrm{d}}$ & $65.56^{\mathrm{c}}$ \\
\hline Catechin-glucoside & $23.87^{\mathrm{b}}$ & $34.97^{\mathrm{a}}$ & $1.88^{\mathrm{d}}$ & $13.53^{c}$ \\
\hline Caffeic acid hexose & $41.02^{\mathrm{a}}$ & $37.39^{b}$ & $1.06^{\mathrm{d}}$ & $30.95^{c}$ \\
\hline Catechin & $20.40^{\mathrm{a}}$ & $17.25^{\mathrm{b}}$ & $1.36^{\mathrm{d}}$ & $7.33^{c}$ \\
\hline Swertiamacroside & $33.14^{\mathrm{a}}$ & $22.81^{b}$ & $0.85^{\mathrm{d}}$ & $9.84^{\mathrm{c}}$ \\
\hline Caffeic acid & $36.82^{a}$ & $22.35^{\mathrm{b}}$ & $0.15^{\mathrm{d}}$ & $0.96^{\mathrm{c}}$ \\
\hline Epicatechin & $69.56^{\mathrm{a}}$ & $26.48^{\mathrm{b}}$ & $2.60^{\mathrm{d}}$ & $14.01^{\mathrm{c}}$ \\
\hline (Epi)afzelchin-(epi) catechin isomer A & $58.11^{\mathrm{a}}$ & $35.49^{\mathrm{b}}$ & $1.71^{\mathrm{d}}$ & $20.06^{c}$ \\
\hline Orientin & $5.18^{\mathrm{a}}$ & $3.79^{b}$ & $0.02^{\mathrm{d}}$ & $1.58^{\mathrm{c}}$ \\
\hline Isorientin & $4.61^{\mathrm{a}}$ & $2.84^{\mathrm{b}}$ & $<\mathrm{LOQ}$ & $0.82^{c}$ \\
\hline Vitexin & $9.14^{\mathrm{a}}$ & $6.26^{\mathrm{b}}$ & $0.06^{\mathrm{d}}$ & $2.02^{c}$ \\
\hline Rutin & $214.99^{\text {a }}$ & $148.63^{\mathrm{b}}$ & $7.03^{d}$ & $87.33^{\mathrm{c}}$ \\
\hline Epicatechin-gallate & $18.56^{\mathrm{a}}$ & $7.82^{b}$ & $0.28^{\mathrm{d}}$ & $5.22^{\mathrm{c}}$ \\
\hline Epiafzelchin-epiafzelchin-epicatechin & $20.37^{\text {a }}$ & $12.69^{\mathrm{b}}$ & $0.84^{\mathrm{d}}$ & $8.01^{\mathrm{c}}$ \\
\hline Swertiamacroside & $27.41^{\mathrm{a}}$ & $20.92^{b}$ & $4.23^{\mathrm{d}}$ & $9.47^{\mathrm{c}}$ \\
\hline Hyperin & $2.84^{\mathrm{a}}$ & $1.59^{\mathrm{b}}$ & $<\mathrm{LOQ}$ & $0.13^{c}$ \\
\hline Epiafzelchin-epicatechin-O-methyl gallate & $76.84^{a}$ & $39.84^{b}$ & $1.00^{\mathrm{d}}$ & $28.73^{c}$ \\
\hline (-)-Epicatechin-3-(3"-O-methyl) gallate & $31.61^{\mathrm{a}}$ & $17.77^{\mathrm{b}}$ & $0.51^{\mathrm{d}}$ & $15.18^{c}$ \\
\hline (Epi)afzelchin-(epi) catechin isomer B & $25.04^{\mathrm{a}}$ & $15.03^{\mathrm{b}}$ & $0.47^{\mathrm{d}}$ & $9.95^{c}$ \\
\hline Procyanidin B2-dimethylgallate & $51.46^{\mathrm{a}}$ & $29.22^{b}$ & $0.67^{\mathrm{d}}$ & $21.06^{\mathrm{c}}$ \\
\hline Epiafzelchin-epicatechin-O-dimethylgallate & $216.94^{\mathrm{a}}$ & $176.67^{\mathrm{b}}$ & $13.11^{\mathrm{d}}$ & $93.83^{c}$ \\
\hline Epicatechin-O-3,4-dimethylgallate & $98.07^{\mathrm{a}}$ & $8.05^{\mathrm{c}}$ & $2.31^{\mathrm{d}}$ & $39.10^{\mathrm{b}}$ \\
\hline Isoquercitrin & $1.41^{\mathrm{a}, \mathrm{b}}$ & $2.05^{\mathrm{a}}$ & $0.54^{\mathrm{d}}$ & $1.09^{\mathrm{c}}$ \\
\hline Quercetin & $33.21^{\mathrm{a}}$ & $12.39^{b}$ & $0.06^{\mathrm{d}}$ & $2.27^{\mathrm{c}}$ \\
\hline Flavonoids & $982.23^{a}$ & $598.23^{b}$ & $34.47^{\mathrm{d}}$ & $371.25^{c}$ \\
\hline Phenolic acids & $260.26^{\mathrm{b}}$ & $302.28^{\text {a }}$ & $11.89^{\mathrm{d}}$ & $149.49^{c}$ \\
\hline Sum & $1242.49^{\mathrm{a}}$ & $901.10^{\mathrm{b}}$ & $46.36^{\mathrm{d}}$ & $520.74^{c}$ \\
\hline
\end{tabular}

Different letters in the same line show significant differences $(p<0.05)$, LOQ: Limit of quantification.

The most concentrated free phenolic compound in all buckwheat flours was epiafzelchin-epicatechin-O-dimethylgallate, whose content was $13.11 \mathrm{mg} / \mathrm{kg}$ d.w. in light flour, $93.83 \mathrm{mg} / \mathrm{kg}$ d.w. in de-hulled grain meal, $176.67 \mathrm{mg} / \mathrm{kg}$ d.w. in middling flour, and $216.94 \mathrm{mg} / \mathrm{kg}$ d.w. in bran meal. The second most concentrated in buckwheat flours was rutin, whose content was from $7.03 \mathrm{mg} / \mathrm{kg}$ d.w in light flour, $87.33 \mathrm{mg} / \mathrm{kg}$ d.w. in de-hulled grain meal, $148.63 \mathrm{mg} / \mathrm{kg} \mathrm{d} . w$. in middling flour, to $214.99 \mathrm{mg} / \mathrm{kg} \mathrm{d} . \mathrm{w}$ in bran meal. Thus, the most abundant free flavonoids are present in buckwheat bran meal, followed by middling flour, de-hulled buckwheat meal, and light flour. Besides, 2-hydroxy-3-O- $\beta$-D-glucopyranosylbenzoic and protocatechuic-4-O-glucoside acid appear in buckwheat fractions in significant quantities, whose values were $2.67-2.93 \mathrm{mg} / \mathrm{kg}$ d.w. in light flour, $32.71-65.56 \mathrm{mg} / \mathrm{kg}$ in de-hulled grain meal, $42.17-79.69 \mathrm{mg} / \mathrm{kg}$ d.w. in bran meal, and 78.22-120.56 $\mathrm{mg} / \mathrm{kg} \mathrm{d.w}$. in middling flour. Therefore, the highest content of phenolic acids appears in middling flour, followed by bran meal, de-hulled grain meal, and light flour. The third most abundant phenolic compound in middling and de-hulled grain meal was protocatechuic-4-O-glucoside acid (120.59 and $65.56 \mathrm{mg} / \mathrm{kg} \mathrm{d.w.)}$, whereas in light flour was swertiamacroside ( $4.23 \mathrm{mg} / \mathrm{kg} \mathrm{d.w.)}$, and in bran meal was epicatechin-O-3,4-dimethylgallate ( $98.07 \mathrm{mg} / \mathrm{kg}$ d.w.).

The total free phenolic content in buckwheat flours was decreasing in the following order: bran meal $>$ middling flour $>$ de-hulled buckwheat meal $>$ light flour $(1242.49,901.10,520.74$, and 46.36 $\mathrm{mg} / \mathrm{kg} \mathrm{d.w.).} \mathrm{These} \mathrm{results} \mathrm{are} \mathrm{due} \mathrm{to} \mathrm{the} \mathrm{most} \mathrm{abundant} \mathrm{free} \mathrm{phenolic} \mathrm{compounds} \mathrm{being} \mathrm{flavonoids,}$ which corresponded to $66-79 \%$ of total free phenolic compounds, and these are found in higher concentration in outer layers than in inner layers of buckwheat grain [2]. For that reason, bran meal contains the highest content of free phenolic compounds, followed by middling flour, as it contains seed coat.

The concentration of free phenolic compounds obtained in buckwheat was compared with that obtained previously in other works. Verardo et al. (2011) [5] quantified the individual free phenolic compounds in de-hulled buckwheat grain, where rutin was the most concentrated, whose value was $35.12 \%$ higher than that obtained in the present work and total content of free phenolic compounds was $48.39 \%$ higher than in the present work. Nevertheless, the most concentrated free phenolic compound in our work was epiafzelchin-epicatechin-O-dimethylgallate, whose value was $50 \%$ higher 
than that obtained by Verardo et al. (2011) [5]. These differences of concentration could be due to the different buckwheat cultivar. Besides, Inglett et al. (2011) [18] quantified the free flavonoid content in different buckwheat flours (fancy, farinetta, supreme, and whole), fancy corresponded with light flour, supreme flour is similar to bran meal, farinetta consists of a fine granulated mixture of aleurone layer of hulled achene and achene embryo, a composition similar to middling flour $[19,20]$. The value of free flavonoids obtained in our study in light flour, de-hulled grain meal, bran meal, and middling flour (34.47 mg/kg d.w., $371.25 \mathrm{mg} / \mathrm{kg}$ d.w., $982.23 \mathrm{mg} / \mathrm{kg}$ d.w., and $598.83 \mathrm{mg} / \mathrm{kg} \mathrm{d.w}$ ) were in the same order of magnitude than that obtained in fancy (71.40 mg/kg d.w.), whole buckwheat flour $(417.03 \mathrm{mg} / \mathrm{kg}$ d.w.), supreme (525.27 mg/kg d.w.), and farinetta (671.50 mg/kg d.w.) by Inglett et al. (2011) [18].

Hung et al. (2008) [2] reported the content of rutin in the free form obtained in different buckwheat flour fractions, and its concentration was $2.5-3 \mathrm{mg} / \mathrm{kg} \mathrm{d.w}$. in the innermost layers, whereas in the outer layers, it was $274-337.8 \mathrm{mg} / \mathrm{kg}$. These results were similar to those obtained in the present work in the light flour (7.03 mg/kg dw.) and bran meal (214.99 mg/kg d.w.). Kalinová et al. (2019) [21] reported the free phenolic compounds in the seed coat $(553.18 \mathrm{mg} / \mathrm{kg} \mathrm{d.w.})$, in the endosperm $(2.59$ $\mathrm{mg} / \mathrm{kg} \mathrm{d.w.)}$, and in the groat (139.66 mg/kg d.w.). These values were lower than those obtained in bran meal, light flour, and de-hulled grain meal, and also, the content of rutin in seed coat $(54.23 \mathrm{mg} / \mathrm{kg}$ d.w.) represents a quart of the phenolic bran meal $(214.99 \mathrm{mg} / \mathrm{kg} \mathrm{d} . w$.$) obtained in our study. This$ could be due to the different cultivar and/or the different methodology of determination of phenolic compounds (by MS detection a higher number of compounds are determined).In addition, Liu et al. (2019) [22] reported the concentration of rutin in common buckwheat $(62.19 \mathrm{mg} / \mathrm{kg} \mathrm{d.w.})$ that was in the same order as that obtained in de-hulled grain meal $(87.33 \mathrm{mg} / \mathrm{kg} \mathrm{d.w.}$.). According to the results obtained in these previous works, it has shown that rutin in the free form is concentrated in the outer layers, which is in concordance with our results.

The Table 5 reports the content of bound phenolic compounds in buckwheat flours. Bound phenolic compounds composition in buckwheat flours was similar than that obtained in free phenolic fraction; nevertheless, flavonoids such as isorientin, epiafzelchin-epiafzelchin-epicatechin, Procyanidin B2-dimethylgallate, hyperin, and (epi)afzelchin-(epi)catechin were not detected in bound fraction, whereas some phenolic acids such as syringic and p-coumaric acid, procyanidin A, and myricetin were determined only in bound fraction.

Catechin was the most concentrated bound phenolic compound in all buckwheat flours, representing $25-30 \%$ of total bound phenolic compounds, and its concentration was $54.67 \mathrm{mg} / \mathrm{kg}$ d.w. in light flour, $95.45 \mathrm{mg} / \mathrm{kg}$ d.w. in de-hulled grain meal, $200.17 \mathrm{mg} / \mathrm{kg} \mathrm{d} . w$. in middling flour, and $207.74 \mathrm{mg} / \mathrm{kg}$ d.w. in bran meal, respectively. The second component most abundant was epicatechin, whose content was $34.67 \mathrm{mg} / \mathrm{kg}$ d.w. in light flour, $41.55 \mathrm{mg} / \mathrm{kg}$ d.w. in de-hulled grain meal, 59.08 $\mathrm{mg} / \mathrm{kg}$ d.w. in bran flour, and $97.50 \mathrm{mg} / \mathrm{kg}$ d.w. in middling flour. The third most abundant phenolic compound in de-hulled grain meal and bran meal was syringic acid $(35.62 \mathrm{mg} / \mathrm{kg}$ d.w. and $85.86 \mathrm{mg} / \mathrm{kg}$ d.w.), whereas in middling flour it was caffeic acid hexose (56.73 mg/kg d.w.), and in light flour it was swertiamacroside.

The total bound phenolic content in buckwheat flours was increasing in the following order: light flour < de-hulled grain meal < bran meal < middling flour $(207.74,389.51,689.81$, and 704.47 $\mathrm{mg} / \mathrm{kg} \mathrm{d}$.w.). Therefore, the highest concentration of bound phenolic compounds is in middling and bran meal due to these compounds being linked to the cell wall of buckwheat layers. Flavonoids represented $59-65 \%$ of the bound phenolic fraction. Whereas, phenolic acids represented $35-41 \%$ of bound phenolic fraction.

Concentrations of catechin, epicatechin, syringic, and total bound phenolic compounds in de-hulled whole buckwheat flour obtained by Verardo et al. (2011) [5] were $23.88 \%$, 48.54\%, and $53.18 \%$ higher than those obtained in the present work. Inglett et al. (2011) [18] reported the content of total bound flavonoid in buckwheat flour fractions obtained was $59.25 \mathrm{mg} / \mathrm{kg}$ d.w. in fancy, $389.68 \mathrm{mg} / \mathrm{kg}$ in farinetta, $530.21 \mathrm{mg} / \mathrm{kg}$ in supreme, and $613.77 \mathrm{mg} / \mathrm{kg} \mathrm{d} . \mathrm{w}$. in whole flour, which are in the same order of magnitude as that obtained in our work. Nevertheless, in this study, the highest bound phenolic 
content was obtained in whole buckwheat flour, whereas in our work, the maximum value of phenolic content corresponded with the middling flour. This could be due to the different cultivar or because Inglett et al. (2011) [18] could include the hull in the buckwheat grain flour.

Table 5. Bound phenolic compounds quantified in buckwheat meals/flours ( $\mathrm{mg} / \mathrm{kg} \mathrm{d.w.)} \mathrm{determined}$ by HPLC-MS.

\begin{tabular}{|c|c|c|c|c|}
\hline Bound Phenolic Compounds & Bran Meal & Middling Flour & Light Flour & De-Hulled Grain Meal \\
\hline 2-hydroxy-3-O- $\beta$-D-glucopyranosylbenzoic acid & $23.02^{b}$ & $34.56^{\mathrm{a}}$ & $6.19^{\mathrm{c}, \mathrm{d}}$ & $7.88^{\mathrm{d}}$ \\
\hline Protocatechuic-4-O-glucoside acid & $18.44^{\mathrm{b}}$ & $25.50^{\mathrm{a}}$ & $5.51^{\mathrm{c}}$ & $5.95^{\mathrm{c}}$ \\
\hline Caffeic acid hexose isomer a & $5.52^{\mathrm{b}}$ & $11.34^{\mathrm{a}}$ & $0.67^{c}$ & $0.43^{c, d}$ \\
\hline Caffeic acid hexose isomer $b$ & $40.42^{b}$ & $56.73^{\mathrm{a}}$ & $13.28^{d}$ & $26.35^{c}$ \\
\hline Catechin & $207.74^{\text {a }}$ & $200.17^{\text {a }}$ & $54.67^{\mathrm{c}}$ & $95.45^{b}$ \\
\hline Swertiamacroside & $23.25^{c, d}$ & $31.84^{a, b}$ & $25.40^{\mathrm{d}}$ & $33.66^{\mathrm{a}}$ \\
\hline Caffeic acid & $<\mathrm{LOQ}$ & $<$ LOQ & $<$ LOQ & $<\mathrm{LOQ}$ \\
\hline Epicatechin & $59.08^{\mathrm{b}}$ & $97.50^{\mathrm{a}}$ & $34.67^{\mathrm{d}}$ & $41.55^{\mathrm{c}}$ \\
\hline Syringic acid & $85.86^{\mathrm{a}}$ & $43.57^{\mathrm{b}}$ & $7.74^{\mathrm{d}}$ & $35.62^{c}$ \\
\hline Orientin & $0.46^{\mathrm{a}}$ & $0.56^{\mathrm{a}}$ & $0.19^{c}$ & $0.22^{b}$ \\
\hline$p$-coumaric acid derivative & $9.65^{\text {a }}$ & $3.53^{\mathrm{b}}$ & $1.39^{\mathrm{d}}$ & $3.24^{c}$ \\
\hline Procyanidin A & $8.82^{\mathrm{a}}$ & $9.03^{\mathrm{a}}$ & $0.95^{c}$ & $4.95^{b}$ \\
\hline Myricetin & $4.12^{\mathrm{a}}$ & $3.80^{\mathrm{a}}$ & $2.06^{b, c}$ & $2.92^{b}$ \\
\hline Vitexin & $4.22^{\mathrm{a}}$ & $3.86^{\mathrm{a}}$ & $0.67^{\mathrm{c}}$ & $2.30^{\mathrm{b}}$ \\
\hline Rutin & $51.64^{\text {a }}$ & $45.19^{\mathrm{b}}$ & $6.82^{d}$ & $33.71^{\mathrm{c}}$ \\
\hline Epicatechin gallate & $16.24^{\mathrm{a}}$ & $15.57^{\mathrm{a}}$ & $4.21^{\mathrm{c}}$ & $10.75^{b}$ \\
\hline Catechin-glucoside & $16.48^{\mathrm{a}}$ & $17.51^{\mathrm{a}}$ & $1.04^{\mathrm{c}}$ & $13.26^{\mathrm{b}}$ \\
\hline Swertiamacroside & $39.40^{\mathrm{a}}$ & $32.37^{b}$ & $23.52^{\mathrm{d}}$ & $30.43^{c}$ \\
\hline Epiafzelchin-epicatechin-O-methylgallate & $28.04^{\text {a }}$ & $27.81^{\text {a }}$ & $3.57^{\mathrm{c}}$ & $9.72^{b}$ \\
\hline$p$-coumaric acid & $3.96 \mathrm{~b}$ & $6.91^{\mathrm{a}}$ & $0.67^{\mathrm{d}}$ & $2.74^{\mathrm{c}}$ \\
\hline (-)-epicatechin-3-(3"-O-methyl) gallate & $6.09^{\mathrm{a}}$ & $6.05^{\mathrm{a}}$ & $2.06^{\mathrm{c}}$ & $4.17^{\mathrm{b}}$ \\
\hline Epicatechin-O-3,4-dimethylgallate & $4.65^{\mathrm{a}}$ & $4.11^{\mathrm{a}}$ & $0.50^{c}$ & $1.78^{b}$ \\
\hline Isoquercitrin & $6.06^{\mathrm{a}}$ & $5.89^{\mathrm{a}}$ & $1.03^{c}$ & $3.64^{b}$ \\
\hline Quercitrin & $26.64^{\mathrm{a}}$ & $21.05^{b}$ & $10.94^{\mathrm{d}}$ & $18.78^{c}$ \\
\hline Flavonoids & $440.29^{b}$ & $458.11^{a}$ & $123.37^{\mathrm{d}}$ & $243.20^{c}$ \\
\hline Phenolic acids & $249.52^{\text {a }}$ & $246.35^{\mathrm{b}}$ & $84.37^{\mathrm{d}}$ & $146.31^{\mathrm{c}}$ \\
\hline Total & $689.81^{b}$ & $704.47^{\text {a }}$ & $207.74^{\mathrm{d}}$ & $389.51^{c}$ \\
\hline
\end{tabular}

Different letters in the same line show significant differences $(p<0.05)$, LOQ: Limit of quantification.

The total content of flavonoids was from $157.84 \mathrm{mg} / \mathrm{kg} \mathrm{d}$.w. in light flour to $1422.52 \mathrm{mg} / \mathrm{kg} \mathrm{d.w}$. in bran meal, whereas the content of phenolic acids was from $96.261 \mathrm{mg} / \mathrm{kg} \mathrm{d}$.w. in light flour to $548.63 \mathrm{mg} / \mathrm{kg} \mathrm{d.w}$. in middling flour. Total phenolic content was from $254.10 \mathrm{mg} / \mathrm{kg} \mathrm{d}$.w. in light flour to $1932.30 \mathrm{mg} / \mathrm{kg} \mathrm{d.w}$. in bran meal (Table 6). According to the results, the total phenolic content was increasing in the following order: light flour $<$ de-hulled grain meal $<$ middling flour $<$ bran meal Therefore, middling flour and bran meal possess the highest phenolic content due to bran and the aleurone layer being richer in many phenolic compounds than the others buckwheat flours [23]. Total flavonoid obtained in de-hulled grain meal, bran meal, and middling flour was $49.22 \%, 71.21 \%$, and $27.83 \%$ higher than that obtained in whole grain meal, supreme, and farinetta by liquid chromatography-electrospray ionization- mass spectrometry (LC-ESI-MS) [18]. According to Guo and co-workers, free rutin was determined in a range of 51-81\% [24].

Table 6. Total content of flavonoids, phenolic acids, and phenolic compounds in buckwheat flours. Results are expressed as $\mathrm{mg} / \mathrm{kg}$ d.w.

\begin{tabular}{cccc}
\hline & Flavonoids & Phenolic Acids & Total \\
\hline Bran meal & $1422.52^{\mathrm{a}}$ & $509.78^{\mathrm{b}}$ & $1932.30^{\mathrm{a}}$ \\
Middling flour & $1056.94^{\mathrm{b}}$ & $548.63^{\mathrm{a}}$ & $1605.57^{\mathrm{b}}$ \\
Light flour & $157.84^{\mathrm{d}}$ & $96.261^{\mathrm{d}}$ & $254.10^{\mathrm{d}}$ \\
De-hulled grain meal & $614.46^{\mathrm{c}}$ & $295.80^{\mathrm{c}}$ & $910.25^{\mathrm{c}}$ \\
\hline
\end{tabular}

Different letters in the same column show significant differences $(p<0.05)$.

\section{Conclusions}

An HPLC-MS has been used for the determination of free and bound phenolic compounds in buckwheat flours: middling flour, bran meal, light flour, and whole meal. The results of this study 
have shown that the total free phenolic compounds are found in the highest concentration in bran meal, whereas the bound content of phenolic compounds are concentrated in middling flour and bran meal. In buckwheat flours, the main flavonoids were rutin and epiafzelchin-epicatechin-O-dimethylgallate, which had the greatest content in bran meal. By contrast, catechin and epicatechin were the main bound flavonoids in buckwheat meal/flours that existed in the greatest quantities in middling and bran fours.

To conclude, the bran meal and middling flour could be considered as flours enriched in phenolic compounds that could be used to elaborate food with health benefits. Moreover, it has been proved, as the distribution of some phenolic compound varied from bran to middling fraction.

Author Contributions: Conceptualization, V.V., E.M., and A.M.G.-C.; Investigation, B.M.-G. and F.P.; Supervision, V.V., A.M.G.-C., and M.F.C.; Writing—original draft, B.M.-G.; Writing—review \& editing, F.P., V.V., A.M.G.-C., E.M., and M.F.C.

Funding: This research received no external funding.

Acknowledgments: V.V. thanks the Spanish Ministry of Economy and Competitiveness (MINECO) for “Ramon y Cajal" contract (RYC-2015-18795). B.M.G. would like to thank to the University of Granada "Convocatoria de movilidad internacional de estudiantes de doctorado" grant.

Conflicts of Interest: The authors declare no conflict of interest.

\section{References}

1. Sytar, O. Phenolic acids in the inflorescences of different varieties of buckwheat and their antioxidant activity. J. King Saud Univ.Sci. 2015, 27, 136-142. [CrossRef]

2. Van Hung, P.; Morita, N. Distribution of phenolic compounds in the graded flours milled from whole buckwheat grains and their antioxidant capacities. Food Chem. 2008, 109, 325-331. [CrossRef] [PubMed]

3. Zhang, Z.; Zhou, M.; Tang, Y.; Li, F.; Tang, Y.; Shao, J. Bioactive compounds in functional buckwheat food. FRIN 2012, 49, 389-395. [CrossRef]

4. Verardo, V.; Arráez-Román, D.; Segura-Carretero, A.; Marconi, E.; Fernández-Gutiérrez, A.; Caboni, M.F. Identification of buckwheat phenolic compounds by reverse phase high performance liquid chromatography e electrospray ionization-time of flight-mass spectrometry (RP-HPLC e ESI-TOF-MS). J. Cereal Sci. 2010, 52, 170-176. [CrossRef]

5. Verardo, V.; Arráez-Román, D.; Segura-Carretero, A.; Marconi, E.; Fernández-Gutiérrez, A.; Caboni, M.F. Determination of free and bound phenolic compounds in buckwheat spaghetti by RP-HPLC-ESI-TOF-MS: Effect of thermal processing from farm to fork. J. Agric. Food Chem. 2011, 59, 7700-7707. [CrossRef]

6. Sedej, I.; Sakač, M.; Mandić, A.; Mišan, A.; Tumbas, V.; Čanadanović-Brunet, J. Buckwheat (Fagopyrum esculentum Moench) Grain and Fractions: Antioxidant Compounds and Activities. J. Food Sci. 2012, 77, C954-C959. [CrossRef]

7. Kaliora, A.C.; Dedoussis, G.V.Z. Natural antioxidant compounds in risk factors for CVD. Pharmacol. Res. 2007, 56, 99-109. [CrossRef]

8. Ma, M.S.; In, Y.B.; Hyeon, G.L.; Yang, C.B. Purification and identification of angiotensin I-converting enzyme inhibitory peptide from buckwheat (Fagopyrum esculentum Moench). Food Chem. 2006, 96, 36-42. [CrossRef]

9. Giménez-Bastida, J.A.; Zieliński, H. Buckwheat as a Functional Food and Its Effects on Health. J. Agric. Food Chem. 2015, 63, 7896-7913. [CrossRef]

10. Chan, P.K. Inhibition of tumor growth in vitro by the extract of fagopyrum cymosum (fago-c). Life Sci. 2003, 72, 1851-1858. [CrossRef]

11. Alvarez-Jubete, L.; Wijngaard, H.; Arendt, E.K.; Gallagher, E. Polyphenol composition and in vitro antioxidant activity of amaranth, quinoa buckwheat and wheat as affected by sprouting and baking. Food Chem. 2010, 119, 770-778. [CrossRef]

12. Bobkov, S. Biochemical and Technological Properties of Buckwheat Grains. In Molecular Breeding and Nutritional Aspects of Buckwheat; Zhou, M., Kreft, I., Woo, S.H., Chrungoo, N., Wieslander, G., Eds.; Elsevier: Oxford, UK, 2016; pp. 423-440.

13. Bonafaccia, G.; Marocchini, M.; Kreft, I. Composition and technological properties of the flour. Food Chem. 2003, 80, 9-15. [CrossRef] 
14. Dreher, M. Food sources and uses of dietary fiber. In Complex Carbohydrates in Foods; Sungsoo cho, S., Ed.; CRC Press: Boca Raton, FL, USA, 1999; pp. 358-359.

15. Liu, F.; He, C.; Wang, L.; Wang, M. Effect of milling method on the chemical composition and antioxidant capacity of Tartary buckwheat flour. Int. J. Food Sci. Technol. 2018, 53, 2457-2464. [CrossRef]

16. Morita, N.; Maeda, T.; Sai, R.; Miyake, K.; Yoshioka, H.; Urisu, A.; Adachi, T. Studies on distribution of protein and allergen in graded flours prepared from whole buckwheat grains. Food Res. Int. 2006, 39, 782-790. [CrossRef]

17. Gómez-Caravaca, A.M.; Verardo, V.; Berardinelli, A.; Marconi, E.; Caboni, M.F. A chemometric approach to determine the phenolic compounds in different barley samples by two different stationary phases: A comparison between C18 and pentafluorophenyl core shell columns. J. Chromatogr. A 2014, 1355, 134-142. [CrossRef]

18. Inglett, G.E.; Chen, D.; Berhow, M.; Lee, S. Antioxidant activity of commercial buckwheat flours and their free and bound phenolic compositions. Food Chem. 2011, 125, 923-929. [CrossRef]

19. Inglett, G.E.; Xu, J.; Stevenson, D.G.; Chen, D. Rheological and pasting properties of buckwheat (Fagopyrum esculentum Möench) flours with and without jet-cooking. Cereal Chem. 2009, 86, 1-6. [CrossRef]

20. Steadman, K.J.; Burgoon, M.S.; Lewis, B.A.; Edwardson, S.E.; Obendorf, R.L. Buckwheat seed milling fractions: Description, macronutrient composition and dietary fibre. J. Cereal Sci. 2001, 33, 271-278. [CrossRef]

21. Kalinová, J.P.; Vrchotováb, N.; Tř́íska, J. Phenolics levels in different parts of common buckwheat (Fagopyrum esculentum) achenes. J. Cereal Sci. 2019, 85, 243-248. [CrossRef]

22. Liu, Y.; Cai, C.; Yao, Y.; Xu, B. Alteration of phenolic profiles and antioxidant capacities of common buckwheat and tartary buckwheat produced in China upon thermal processing. J. Sci. Food Agric. 2019, 99, 5565-5576. [CrossRef]

23. Fu-Hua, L.; Yuan, Y.; Xiao-lan, Y.; Shu-ying, T.; Jian, M. Phenolic Profiles and Antioxidant Activity of Buckwheat (Fagopyrum esculentum Möench and Fagopyrum tartaricum L. Gaerth) Hulls, Brans and Flours. J. Integr. Agric. 2013, 12, 1684-1693.

24. Guo, X.D.; Wu, C.S.; Ma, Y.J.; Parry, J.; Xu, Y.Y.; Liu, H.; Wang, M. Comparison of milling fractions of tartary buckwheat for their phenolics and antioxidant properties. Food Res. Int. 2012, 49, 53-59. [CrossRef]

(C) 2019 by the authors. Licensee MDPI, Basel, Switzerland. This article is an open access article distributed under the terms and conditions of the Creative Commons Attribution (CC BY) license (http://creativecommons.org/licenses/by/4.0/). 